\title{
Inter-specific variation in susceptibility to grazing among common reef corals
}

\author{
A. J. Cole*, M. S. Pratchett \\ ARC Centre of Excellence for Coral Reef Studies, James Cook University, Townsville, Queensland 4811, Australia
}

\begin{abstract}
Many species of reef fishes, such as butterflyfishes and wrasses, feed almost continuously and at very high rates upon reef-building corals. This study quantified grazing rates on 4 common reef corals (Acropora hyacinthus, A. millepora, Pocillopora damicornis, and massive Porites) to assess the variation in susceptibility to coral predation. We also assessed the variation in predation intensity within $A$. hyacinthus and $A$. millepora by standardising grazing rates by colony surface. Rates of grazing on individual colonies were lowest $(0.95 \pm 0.33$ bites per 20 min; mean $\pm \mathrm{SE})$ for massive Porites and highest (16.75 \pm 0.30 bites per $20 \mathrm{~min})$ for A. hyacinthus. Within coral species, grazing rates showed a linear increase with increasing size of the colony; however, the intensity of predation showed a negative relationship with increasing colony size. Predation intensity was highest for small to medium sized colonies with a peak intensity of $1.13 \pm 0.17$ and $0.56 \pm 0.09$ bites per $100 \mathrm{~cm}^{2}$ per $20 \mathrm{~min}$ per colony for for A. hyacinthus and A. millepora colonies (200 to $\left.600 \mathrm{~cm}^{2}\right)$, respectively. In contrast, predation intensity was lowest for both very small and very large colonies, with very small colonies $\left(<200 \mathrm{~cm}^{2}\right)$ rarely being consumed by corallivorous fishes.
\end{abstract}

KEY WORDS: Coral-feeder · Butterflyfish • Corallivory · Energetics · Disturbance · Selective predation

\section{INTRODUCTION}

Predation is a key ecological process, affecting individual fitness, as well the structure and dynamics of both populations and communities (Peckarsky 1980, Sih et al. 1985, Schmitz 2007, Post et al. 2008). In most cases (e.g. among unitary organisms), predation is a discrete event and results in the direct consumption and elimination of prey organisms from the community (Taylor 1984). In this case, differential susceptibility to predation among prey organisms affects their distribution and behaviour (Abramsky et al. 2002, Holmes \& McCormick 2006), and exerts a major influence on the local population and community structure (Anderson 2001, Webster 2003). In contrast, in systems where predation is non-discrete, resulting in only partial consumption or partial mortality (reviewed by Henry \& Hart 2005) such as in many soft-bodied invertebrates and modular organisms such as plants or scleractinian reef corals, these grazing predators can exert a major influence on the fitness of prey organisms, but rarely cause direct mortality (Cox 1986, Skilleter \& Peterson 1994, Irlandi \& Mehlich 1996). For example, partial predation on the siphons of juvenile scallops reduces shell growth by $25 \%$ when exposed to predation. This predation reduces shell growth through the combination of increased regeneration costs and reduced foraging times (Irlandi \& Mehlich 1996).

Coral reef fishes from 11 families totaling 130 species feed directly upon live corals (Cole et al. 2008, Rotjan \& Lewis 2008, Berumen \& Rotjan 2010). The effect of these predators varies greatly, ranging from those which physically damage the carbonate skeleton of corals (e.g. Scaridae, Tetradontidae) to those which only pick at the surface tissues and/or exposed tentacles of individual coral polyps (Hourigan et al. 1988, Tricas 1989), and generally consume only a small part of a coral colony with each bite. Polyp-feeders (e.g Chaetodontidae, Labridae) are the dominant coralfeeders on reefs throughout the Indo-Pacific (Cole et 
al. 2008). Average recorded densities of these coralfeeders range between 12 to 25 ind. per $200 \mathrm{~m}^{2}$ (Fowler 1990, Berumen \& Pratchett 2006, Cole et al. 2010) with most individuals feeding almost continuously and at very high rates (Tricas 1989, Gregson et al. 2008); yet, the potential effects on prey corals are often regarded as negligible (Robertson 1970, Harmelin-Vivien \& Bouchon-Navaro 1983, Hixon 1997, but see Cox 1986). Most polyp-feeders spread their feeding effort across many different colonies distributed throughout relatively large territories and do not leave any visible signs of damage on prey corals (Hourigan et al. 1988, but see Cole et al. 2009a). However, the amount of coral tissue removed by polyp-feeders can be as high as 2 to $3 \mathrm{~g}$ wet weight of coral tissue per day, which implies a significant energetic cost to prey corals (Cole et al. 2011).

Chronic predation by coral-feeding fishes is expected to have significant effects on the structure and dynamics of coral assemblages, especially if there is disproportionate feeding on certain coral species (e.g. Wellington 1982, Cox 1986). Studies that have examined dietary patterns of corallivorous fishes have consistently documented that only a small suite of available coral species are consumed, with most coral-feeders in the Indo-Pacific preferentially selecting Acropora hyacinthus and Pocillopora damicornis above all others (Berumen et al. 2005, Pratchett 2005, 2007, Cole et al. 2008). It is expected that these preferred prey corals will be visited more frequently and will have more bites taken, resulting in these corals experiencing a greater net loss of coral tissue. This concentration of feeding effort has the potential to influence the structure of coral communities; corals that escape predation will have a significant competitive advantage over corals that are frequently consumed. In Hawaii, predation by the corallivorous butterflyfish Chaetodon unimaculatus upon its preferred prey Montipora verrucosa reduces the growth rate and restricts its distribution away from reef margins (Cox 1986). This selective predation also gives adjacent corals a competitive advantage and reverses the outcome of colony interactions, allowing the competitively inferior Porites compressa to overgrow $M$. verrucosa in the presence of predation.

Even within coral species, several factors may lead to differential rates of predation among colonies. Colony size is an especially important characteristic for clonal modular organisms as growth, reproduction and the risk of partial verses total mortality are all strongly related to a coral colony's size (Meesters et al. 2001). It is currently unknown how predation is dispersed between coral colonies of the same species. Optimal foraging theory predicts that larger colonies will receive the highest rates of predation: feeding from these colonies will maximise energy intake as the chance of finding exert polyps will increase (Hughes 1980, Pyke 1984). It is expected that larger colonies will receive a greater rate of predation; however, the consequences of predation in terms of the energetic cost of regeneration may be higher for smaller colonies. When standardized to size, each bite upon a small colony will relate to a higher proportion of the tissue biomass being consumed compared to larger colonies. As regeneration is a function of the surrounding coral tissue (Meesters et al. 1997, Oren et al. 1997, Lirman 2000), these smaller colonies will, potentially, have only limited energy reserves to draw upon, leading to a higher net cost of regeneration (Oren et al. 2001, but see Jayewardene 2010).

The ability of modular organisms to regenerate and recover from grazing injuries is of considerable importance to the health and continued growth of coral reef communities. Although the energy required by corals to regenerate these removed polyps has not been quantified, it has been estimated that a coral polyp takes an average of 7 to $10 \mathrm{~d}$ to successfully regenerate (Gochfeld 2004) and up to $41 \mathrm{~d}$ if the coral skeleton is damaged (Jayewardene 2010). Chronic grazing by polyp-feeding fishes is not expected to cause the death of prey corals directly, but rather will act as a sub-lethal stress. The result is a net drain on the energy reserves of coral colonies as energy spent in regenerating grazed tissue increases instead of being stored as energy reserves or invested in other life-history processes such as growth and reproduction (Cole et al. 2010). Although coral-feeders are unlikely to be the direct cause of coral death, the continual loss of coral tissue may interact with other anthropogenic stresses to increase the rate of overall coral mortality (Bellwood et al. 2006, Cole et al. 2009b).

A key determinant of a coral's ability to survive and recover from a bleaching event is the magnitude of its stored energy reserves (Grottoli et al. 2006, Rodrigues \& Grottoli 2007, Anthony et al. 2009). The 2 most preferred prey corals, Acropora hyacinthus and Pocillopora damicornis, are also 2 of the most susceptible corals to climate-induced mass bleaching (Marshall \& Baird 2000, McClanahan et al. 2004). As such, factors like chronic predation, which have the potential to reduce a colonies energy stores, are likely to have significant consequences on the ability of these frequently eaten corals to survive future bleaching events (Rotjan et al. 2006).

The purpose of the present study is to quantify variation in the frequency and intensity of predation by polypfeeding fishes, within and among common coral species. Specifically we addressed the following questions: (1) Does the frequency of predation vary between 4 common species of reef coral? and (2) Is there a relationship between predation rate and intensity and the size of a coral colony? These questions were addressed over a spatial scale of 3 reefs, to account for differential feeding 
in accordance with local abundance and composition of both the coral community and the population of coralfeeding fishes. The study is focused entirely upon polypfeeding corallivores from the families Labridae and Chaetodontidae, which are the numerically dominant corallivores on most reefs in the Indo-Pacific.

\section{MATERIALS AND METHODS}

Study site. This study was conducted in August and September 2008 on 3 platform reefs on the western side of Kimbe Bay $\left(5^{\circ} 25^{\prime} \mathrm{S}, 150^{\circ} 05^{\prime} \mathrm{E}\right)$, a large sheltered bay on the northern coast of New Britain Island, Papua New Guinea. The 3 study reefs (Lady Di, Luba Luba and No Name) are all isolated platform reefs with steep slopes and shallow reef tops, located $<1 \mathrm{~km}$ from the mainland island of New Britain.

Fish and coral abundances. To assess variation in abundance and composition of coral grazing fishes on each of the 3 reefs, 5 replicate $50 \times 4 \mathrm{~m}$ belt transects were used at each reef. On each transect, all coral-feeding fish observed (>60 $\mathrm{mm}$ ) were recorded to species level and classed as obligate or facultative coral-feeders based on the classification in Cole et al. (2008). On each of these transects, coral community composition was assessed using point-intercept transects, with the substrate directly under the tape recorded to species level at $50 \mathrm{~cm}$ intervals, providing 100 sample points per transect.

To ensure our observations were comparable among the 3 reefs we used separate 1-way analysis of variance (ANOVA) to test for differences in both the abundance of corallivorous fishes and the total cover of live scleractinian corals. Variation in the structure of the coral community was examined using a multivariate analysis of variance (MANOVA) using 7 resource categories (Acropora hyacinthus, A. millepora, other Acropora spp., Pocillopora damicornis, massive Porites spp., Montipora spp. and other hard corals). Pillai's trace statistic was used to determine the significance of the MANOVA result. Tukey's Honestly Significant Difference (HSD) post hoc test was then used to identify which means contributed to any significant differences detected. Residual plots were used to examine univariate and multivariate assumptions of homogeneity and normality.

Frequency of coral predation. Predation frequency was determined using focal animal sampling (Lehner 1996) for 4 common coral species: Acropora hyacinthus, A. millepora, Pocillopora damicornis and massive Porites colonies. From each species, 40 randomly chosen colonies (>25 cm diameter) were observed for $20 \mathrm{~min}$ each. During an observation, each coral was watched from a distance of $5 \mathrm{~m}$, and all bites taken by corallivorous fish was recorded to species level. Following each observation, the length, width and height were measured for each colony. A 2-way ANOVA was used to test for differences in predation rates between species and between reefs. ANOVA assumptions were checked using residual plots. Tukey's HSD test was used to identify where differences in group means occurred.

Intensity of coral predation. To quantify variation in predation rates among colonies of different sizes, a total of 163 colonies of Acropora hyacinthus and 153 colonies of $A$. millepora were observed for $20 \mathrm{~min}$, and the total number of bites taken by each corallivore species was recorded. To quantify the size of coral colonies, the 2-dimensional horizontal surface area $(S)$ was calculated using the equation of an ellipse: $S=$ $\pi\left(d_{1} d_{2}\right) / 4$, where $d_{1}$ and $d_{2}$ are the minor and major axes, respectively, and assuming all colonies were approximately circular, following Hall \& Hughes (1996). Predation intensity was determined for each colony by dividing the number of bites taken during a 20 min observation by the planar $S$ of the colony to give the predation intensity per $\mathrm{cm}^{2}$ of coral. This allowed the predation intensity to be compared among differently sized coral colonies within and between species.

As predation intensity did not show a linear relationship with colony size, we used polynomial regression, which identified a significant relationship between colony size and predation intensity. As the data deviated from a normal distribution, all analyses were run on the natural log of colony area and predation intensity. To identify which colony sizes were driving this non-linear relationship, we assigned each feeding observation into one of 4 size classes: very small $\left(<200 \mathrm{~cm}^{2}\right)$, small $\left(200\right.$ to $\left.600 \mathrm{~cm}^{2}\right)$, medium (600 to $1200 \mathrm{~cm}^{2}$ ) and large (1200 to $2400 \mathrm{~cm}^{2}$ ). As Acropora hyacinthus has a larger size range than A. millepora, a further very large size class $\left(>2400 \mathrm{~cm}^{2}\right)$ was used for this species. Between 21 and 64 colonies were observed within each size class for each species. Two separate 1-way ANOVAs were used to test for differences in predation intensity between size classes for each coral species. Type II sums of squares were used to account for the unequal sample sizes between coral size classes following Langsrud (2003). Tukey's multiple comparison tests were then used to compare the means of treatment groups and identify where differences occurred.

\section{RESULTS}

\section{Abundance of scleractinian coral and coral-feeding fishes}

No significant differences were detected in either the total cover of scleractinian corals (ANOVA df $=2,12, F=$ $0.27, p>0.05$ ) or the densities of corallivorous fishes 
(ANOVA df $=2,12, F=0.6, p>0.05)$ between the 3 reefs. Overall coral cover ranged from $41.2( \pm 5.6)$ to $47.6 \%( \pm 5.0)$. Coral composition did differ slightly between the 3 reefs, with Luba Luba having a significantly (Tukey's HSD p < 0.05) higher cover of Pocillopora damicornis (10.6 $\pm 0.8 \%$ ) compared to No Name $(3.6 \pm 1.3 \%)$ and Lady Di $(5 \pm 0.6 \%)$. No Name reef had the lowest cover of Acropora hyacinthus and A. millepora $(4.2 \pm 0.9$ and $2.4 \pm 0.75 \%$ respectively), compared to Luba Luba $(8.4 \pm 2.1$ and $2.8 \pm 1.1 \%)$ and Lady Di (12 \pm 3.9 and $4.0 \pm 1.1 \%$ ), although these differences were not found to be significant (Tukey's HSD p > 0.05). Five species of obligate coral-feeders (Chaetodon baronessa, C. lunulatus, C. trifascialis, Diproctacanthus xanthurus and Labrichthys unilineatus) and 4 facultative species (C. citrinellus, C. kleinii, C. rafflesi and C. vagabundus) were recorded on the study reefs. Mean abundances of obligate coral-feeding fish ranged from 26.8 $( \pm 3.4)$ to $28.6( \pm 3.2)$ ind. per $200 \mathrm{~m}^{2}$, while facultative coral-feeders had a mean density between $2.6( \pm 1.3)$ and $5.8( \pm 1.5)$ fish per transect. C. baronessa and $L$. unilineatus were the 2 most abundant coral feeders on the 3 reefs and accounted for $82.5 \%$ of all coral feeders observed. This abundance corresponded to the relative contribution to observed bites, with these 2 species accounting for $86.8 \%(3051 / 3513)$ of the total number of bites taken by all corallivores in this study.

\section{Inter-specific differences in the frequency of predation}

The frequency of predation differed significantly between the 4 species of coral, although no difference was detected within a species between the 3 reefs (Table 1, Fig. 1). Likewise, no major differences were detected in the species composition of corallivores that

Table 1. Two-way ANOVA results comparing the frequency of predation among the 4 coral species (Acropora hyacinthus, A. millepora, Pocillopora damicornis and massive Porites spp.) across 3 reefs. Significant values are in bold

\begin{tabular}{|lcccc|}
\hline Source of variation & df & MS & $F$ & $p$ \\
\hline Coral species & 3 & 5373.36 & 79.84 & $<\mathbf{0 . 0 0 0 1}$ \\
Reef & 2 & 35.29 & 0.52 & 0.59 \\
Coral $\times$ Reef & 6 & 29.83 & 0.44 & 0.85 \\
Error & 468 & 67.30 & & \\
\hline
\end{tabular}

fed on each of the coral species, with Chaetodon baronessa and Labrichthys unilineatus accounting for 82 to $90 \%$ of all bites on each of the 4 corals. Acropora hyacinthus received the highest rate of predation with an average ranging from $14.9( \pm 2.7)$ to $16.7( \pm 2.3)$ bites per 20 min per colony. This was significantly (Tukey's HSD $\mathrm{p}<0.001$ ) higher than the predation rate upon any other species and was $37 \%$ higher than the rate felt by the second most frequently eaten coral, Pocillopora damicornis, which received an average bite rate ranging from $8.4( \pm 1.7)$ to $10.5( \pm 2.7)$ bites per $20 \mathrm{~min}$ per colony across the 3 reefs. A. millepora and massive Porites colonies received significantly (Tukey's HSD, $\mathrm{p}>0.05$ ) less predation than either A. hyacinthus or $P$. damicornis. A. millepora received an average rate ranging from $2.1( \pm 0.6)$ to $3.8( \pm 0.9)$ bites per $20 \mathrm{~min}$ per colony while massive Porites colonies rates ranged from $0.95( \pm 0.3)$ to $1.3( \pm 0.6)$ bites per observation. A. hyacinthus and $P$. damicornis also had the highest consistency in predation frequency with 96 (116/120) and $92.5 \%(111 / 120)$ of $A$. hyacinthus and P. damicornis colonies observed receiving predation during an observation, compared to only 65 (78/120) and $41.6 \%$ (50/120) of A. millepora and massive Porites colonies.

\section{Size-specific differences in predation intensity}

Colony size explained 65.7 and $33.4 \%$ of the variation in the number of bites received by colonies of both Acropora hyacinthus and A. millepora (Fig. 2). This 
relationship was largely caused by the absence of predation on very small colonies, with only $21.4 \%(6 / 28)$ of A. hyacinthus and $17.2 \%(5 / 29)$ of A. millepora colonies with a surface area $<200 \mathrm{~cm}^{2}(<15 \mathrm{~cm}$ longest diameter) being preyed upon during an observation compared to $95.6 \%(129 / 135)$ of $A$. hyacinthus and $72.6 \%(90 / 124)$ of $A$. millepora colonies with a surface area $>200 \mathrm{~cm}^{2}$. Further, only $18.6 \%(2 / 11)$ of these very small colonies that were preyed upon received more than one bite during an observation compared to 97.7 (126/129) and 82.2\% (74/90) of larger colonies of $A$. hyacinthus and A. millepora respectively. Although the frequency of predation shows a general increase with increasing size, the actual intensity of predation when standardized to colony surface area declines for larger size classes (Fig. 3).

Coral colony size was found to be a significant factor that influenced the intensity of predation received for both Acropora hyacinthus (ANOVA df $=4,158, F=$
12.23, $\mathrm{p}<0.0001$ ) and A. millepora (ANOVA, df $=$ 3,149, $F=4.71, \mathrm{p}=0.0036)$. Very small colonies $\left(<200 \mathrm{~cm}^{2}\right)$ of both $A$. hyacinthus and A. millepora received the lowest intensity of predation of any size class with an average rate of $0.23( \pm 0.1)$ and 0.15 $( \pm 0.08)$ bites per $100 \mathrm{~cm}^{2}$ per $20 \mathrm{~min}$, respectively (Fig. 3). This rate was significantly (Tukey' HSD p < 0.0001) lower than all other size classes for $A$. hyacinthus and significantly (Tukey' HSD p < 0.01) lower than all but the largest size class for A. millepora. Predation intensity then increased 5-fold to a peak of 1.13 $( \pm 0.17)$ bites per $100 \mathrm{~cm}^{2}$ per $20 \mathrm{~min}$ per colony for small colonies (200 to $600 \mathrm{~cm}^{2}$ ) of $A$. hyacinthus, while predation intensity upon $A$. millepora increased 3 -fold and peaked at $0.56( \pm 0.09)$ bites per $100 \mathrm{~cm}^{2}$ per $20 \mathrm{~min}$ per colony for small sized colonies. Predation intensity then gradually declined with further increases in colony size, with the largest size class of $A$. hyacinthus $\left(>2500 \mathrm{~cm}^{2}\right.$ ) and A. millepora (1200 to $2400 \mathrm{~cm}^{2}$ )
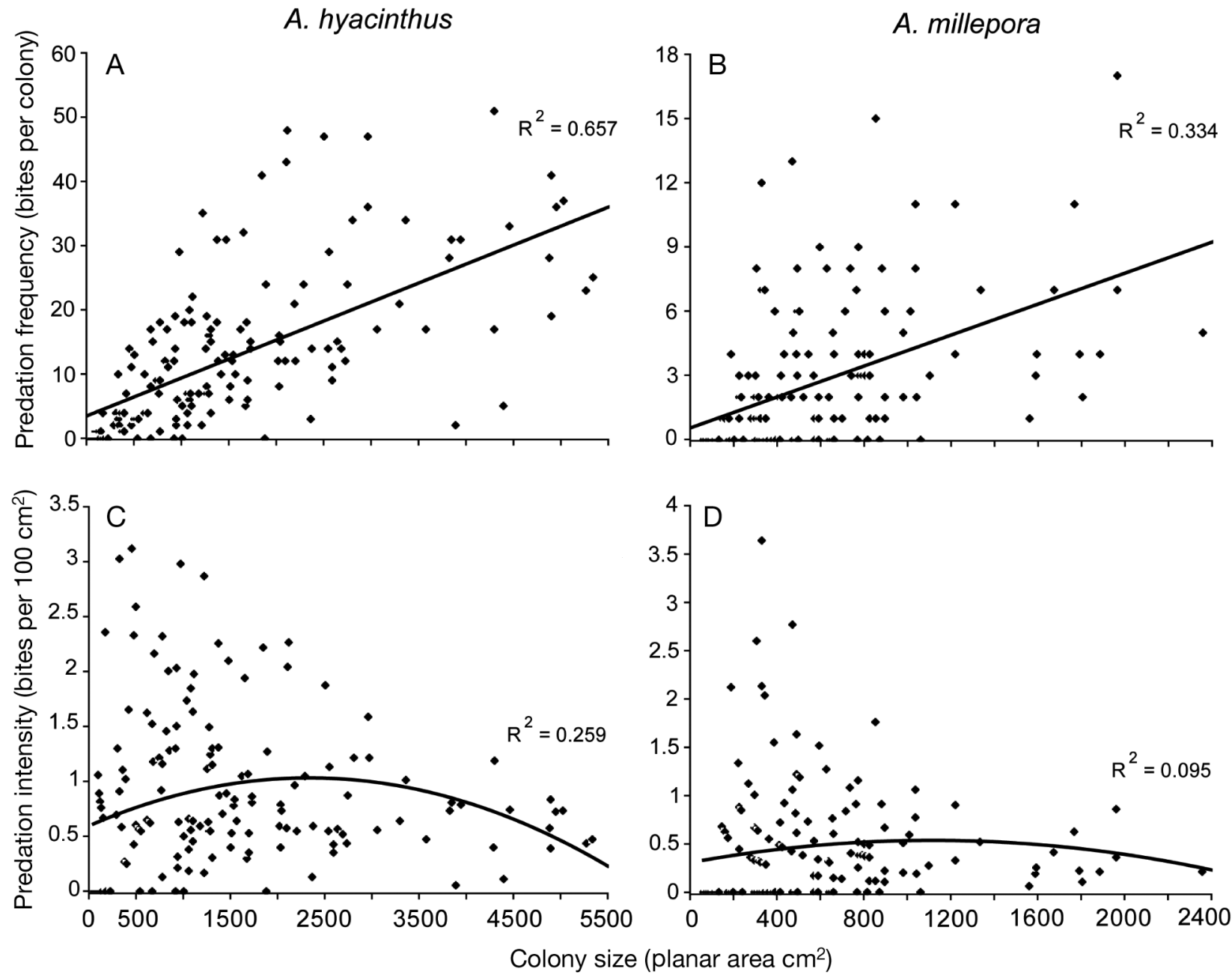

Fig. 2. Acropora hyacinthus and A. millepora. Changes in $(\mathrm{A}, \mathrm{B})$ the number of bites taken by coral-feeding fishes during 20 min observations and $(\mathrm{C}, \mathrm{D})$ predation intensity when the number of bites taken is standardised to colony size, for $A$. hyacinthus and A. millepora respectively 


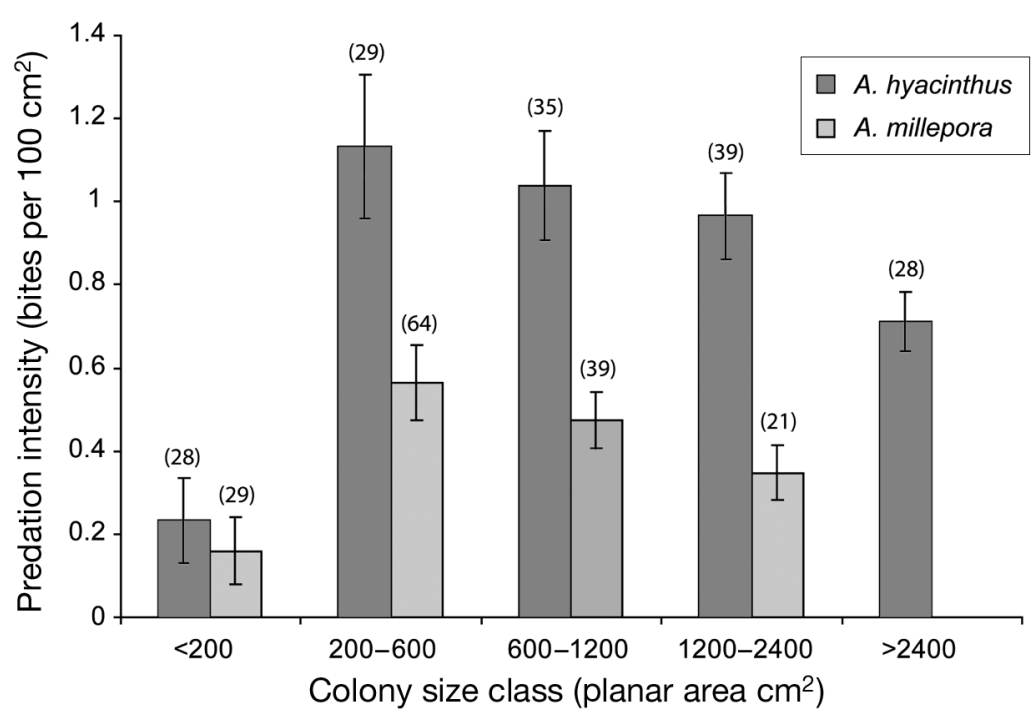

Fig. 3. Acropora hyacinthus and A. millepora. Differences in predation intensity received by coral colonies within 5 size classes for $A$. hyacinthus and A. millepora. Values: mean $\pm \mathrm{SE}$ number of bites taken during 20 min observations standardised to colony size. Numbers in parentheses above bars are number of observations for each size class

receiving an average predation intensity of $0.71( \pm 0.08)$ and $0.35( \pm 0.07)$ bites per $100 \mathrm{~cm}^{2}$ per $20 \mathrm{~min}$, a $40 \%$ decline from the peak intensity received by small colonies.

\section{DISCUSSION}

Previous studies that have tried to assess the effects of chronic fish predation on coral communities have quantified the amount of coral tissue removed across an entire reef system (Harmelin-Vivien \& BouchonNavaro 1981, 1983), implicitly assuming that predation will be distributed evenly across a reef and the subsequent effect of this predation will be uniform across all coral species and colonies. In contrast, our study demonstrates that the frequency and intensity of predation by polyp-feeders differs greatly both within and among coral species. In this study, highest feeding rates were reported for Acropora hyacinthus and Pocillopora damicornis, which received 3 to 16 times more bites than A. millepora and massive Porites species. This finding is consistent with reported feeding preferences of corallivorous fishes that have consistently found that $A$. hyacinthus and $P$. damicornis are consumed in greater proportions than expected based on their availability (Pratchett 2007, Cole et al. 2010), with highly selective corallivores like Chaetodon baronessa and $C$. trifascialis often taking $>80 \%$ of their bites from these 2 corals (Berumen et al. 2005, Pratchett 2005). In the present study, a corresponding result was found with $86.7 \%(3046 / 3513)$ of the total observed bites directed towards A. hyacinthus and $P$. damicornis colonies.

Interestingly, the frequency of predation upon a coral species showed little variability between the 3 study reefs despite a relatively large variation in the composition of the coral community. It was expected that the frequency of predation upon a colony would correspond to the consumer:resource ratio present on each reef. As the abundance of coral consumers was very similar amongst the 3 reefs, we hypothesised that as the relative cover of a preferred coral prey species decreased, the rate of predation received by a colony would increase as selective feeding would cause a concentration of feeding effort. This relationship was not observed for the 2 most frequently consumed corals, Acropora hyacinthus and Pocillopora damicornis, but the inverse relationship was weakly observed for A. millepora and massive Porites colonies. Predation upon these species was highest on the reefs that had the highest availability, which is consistent with the predictions of optimal foraging theory. However, the size of this effect was relatively low compared to the differences in coral availability, e.g. only a 1.5 -fold increase in the rate of predation ( $0.95 \pm 0.29$ vs. $1.38 \pm 0.61$ bites per colony) was observed for a 5.6-fold $(2.4 \pm 0.5 \%$ vs. $13.4 \pm 3.5 \%)$ increase in the availability of massive Porites colonies between the reefs. No relationship was found between coral availability and predation pressure for either of the 2 most frequently eaten prey corals. The average rate of predation on a colony of $A$. hyacinthus differed by only 1.75 bites per colony between reefs even though their was an $8 \%$ difference (range 4 to $12 \%$ ) in relative cover of this coral species. A similar relationship was observed for $P$. damicornis where the average bite rate on Lady Di and Luba Luba differed by only 0.15 bites per colony $(10.32 \pm 2.3$ vs. $10.47 \pm 2.7)$ while the relative cover of $P$. damicornis doubled (5.0 \pm 0.6 vs. $10.6 \pm 0.8$ ) on Luba Luba compared to Lady Di. The lack of a clear relationship between predation pressure and relative coral cover indicates that under healthy reef conditions, grazing pressure is largely independent to coral availability and corals are unlikely to be overgrazed.

The high stability in predation rates between the 3 study reefs suggests that chronic predation by polypfeeding fishes does not appear to be a major force in structuring coral communities, at least in Kimbe Bay. On reefs subjected to frequent or unusual disturbance events, the effect of chronic predation by polyp- 
feeders may become much more pronounced (e.g. Bellwood et al. 2006, Cole et al. 2009b). Reefs in Guam and Moorea have had a long history of disturbance events, from outbreaks of Acanthaster planci to climate-induced mass bleaching events (Done et al. 1991, Burdick et al. 2008, Pratchett et al. 2011). These disturbances have led to major changes in the community structure of coral assemblages (e.g. Gochfeld 2010, Pratchett et al. 2011). Gochfeld's (2010) observations indicate that Acropora and Pocillopora colonies have become extremely rare on some reefs with the distribution of these colonies restricted to spatial refuges inside herbivorous and aggressive damselfish territories. When colonies of Pocillopora damicornis were experimentally transplanted away from these territories, rapid and intense predation occurred and resulted in these colonies being overgrazed, with up to $85 \%$ of accessible tissue being removed within $88 \mathrm{~h}$ (Gochfeld 2010). Undoubtedly, some of the predator response is a result of mechanical disturbance, which has been shown to be a feeding attractant to many corallivores (McIlwain \& Jones 1997, Cole et al. 2009b). Additionally, their study was restricted to only one site at each location, which may not be representative of reefs within the broader region; however, their study does provide strong evidence that coral-feeding butterflyfish can limit the recovery of preferred coral prey on disturbed reefs. Selective predation by coral-feeders did not initially cause the decline in abundance of these corals, but has restricted the recovery of $P$. damicornis and Acropora spp. to refuges free of predation. A similar result was modelled in Hawaii, USA, where the skeletal feeding corallivore Arothron meleagris overgrazes and will potentially prevent the recovery of Porites compressa colonies when the relative cover of this species drops below $5 \%$ (Jayewardene et al. 2009)

An unexpected finding of our study is the absence of predation upon very small colonies $\left(<200 \mathrm{~cm}^{2}\right)$. This size refuge implies that predation from polyp-feeding fishes are unlikely to influence coral growth and mortality of these very small juvenile corals. This finding is in contrast to Penin et al. (2010), who tracked the percentage mortality of juvenile corals around Moorea and found a weak $(\mathrm{R}=0.46)$ but significant correlation between the abundance of chaetodontids at a site and the percentage mortality of juvenile colonies (1 to $5 \mathrm{~cm}$ diameter). They suggested that spatial variation in predation from chaetodontids plays a significant role in the distribution of adult coral populations. This idea seems unlikely considering the findings of Niedermüller et al. (2009) and our observations, in which only 11/57 very small colonies of Acropora hyacinthus and A. millepora were ever fed during an observation. These small colonies received $<1 \%(17 / 2391)$ of the observed bites. Further, the intensity of predation on these very small colonies was the lowest of all size classes, which suggests predation-induced mortality by polyp-feeders on juvenile corals is only likely to occur when these small colonies are the only remaining corals left on a reef (e.g. Samways 2005, Gochfeld 2010). Likewise, very large corals are also expected to experience a lower net effect from chronic predation as the impact of tissue loss is dispersed over a larger surface area, with larger colonies having a greater capacity for regeneration (Oren et al. 2001). In contrast, medium-sized colonies within a size range of 200 to $1200 \mathrm{~cm}^{2}$ of both A. hyacinthus and A. millepora receive the highest intensity of predation. Any negative effects of chronic fish predation are likely to be felt first and foremost by these intermediate-sized colonies with a lessening effect for very small and very large colonies. These potential negative effects include reduced growth rate, larger size at first reproduction and reduced lipid stores as more energy is allocated to regeneration of lost tissue.

Colony size was also found to be an important factor influencing coral consumption in the Red Sea coralfeeding butterflyfish Chaetodon austriacus. This species avoided feeding upon Acropora colonies $<400 \mathrm{~cm}^{2}$ with these colonies consumed in proportions significantly lower than expected given their availability, while it positively selected for all colonies $>400 \mathrm{~cm}^{2}$ (Niedermüller et al. 2009). The factors structuring this avoidance of small colonies are unclear, but are likely to be related to optimal foraging theory. This theory predicts that an organism will try to maximize its energy intake per unit of time (Pyke 1984, Stephens \& Krebs 1986, Tricas 1989, Bergman et al. 2001). Following predation or other local disturbance, corals retract their polyps in the area surrounding the disturbance (e.g. fish bite) (Tricas 1989, Gochfeld 2004, Cole et al. 2010). Repeated feeding in the same location must be delayed long enough for polyps to once again become fully extended (Gochfeld 2004). In our study, on the few occasions when a corallivore did feed upon very small colonies $\left(<200 \mathrm{~cm}^{2}\right)$ it was rare for more than 1 bite to be taken. In contrast, coral-feeders took multiple bites upon larger colonies and spent more time inspecting the coral after each bite. The size and arrangement of potential prey corals will therefore effect the differential feeding on small versus large corals, so as to maximise access to exert polyps.

The regenerative capacity of corals and other modular organisms has been well documented (reviewed by Henry \& Hart 2005). Quantifying the energetic cost of predation has been predominantly confined to relatively large $\left(>1 \mathrm{~cm}^{2}\right)$ man-made injuries (Lirman 2000, Oren et al. 2001, Edmunds \& Lenihan 2010, Lenihan \& Edmunds 2010). Many of these studies have found an energy tradeoff, with regenerating corals showing 
declines in growth and fecundity (Van Veghel \& Bak 1994, Ward 1995, Hall 2001, Oren et al. 2001, Edmunds \& Lenihan 2010, Jayewardene 2010). Only one study has looked at how regeneration of lost tissue and coral growth are related to an actual fish predation injury. The skeletal feeding corallivore Arothron meleagris bites off the growing tips of Porites compressa reducing branch growth rates relative to controls; although no difference in colony growth rates was observed (Jayewardene 2010). Unlike these acute man-made injuries or bites from skeletal-feeders, polyp-feeding corallivores cause numerous small discrete injuries dispersed across the surface of the colony. It takes between 7 to $10 \mathrm{~d}$ to regenerate a grazed polyp (Gochfeld 2004), although the energetic cost of this constant regeneration is unknown. Manipulative experiments are needed to quantify how the chronic stress of polyp-feeding corallivores influences the condition and overall fitness of different coral species and whether this predation reduces their capacity to survive additional stressors such as climate induced bleaching events.

Coral-feeding fishes have traditionally been viewed as a minor component of coral reef dynamics (e.g Hixon 1997). However, the present study and other recent findings (e.g Pratchett 2007, Gochfeld 2010, Cole et al. in press) have all demonstrated that polyp feeding corallivores are a highly selective functional group that consumes considerably more coral tissue than previously suspected. They are capable of having significant effects upon the structure of the coral community, especially after major disturbance events (Bellwood et al. 2006, Gochfeld 2010). The energetic cost imposed by coral-feeders upon coral colonies still needs to be quantified and incorporated into coral reef resilience models, as it is likely that this chronic stress will interact with and be potentially compounded by future anthropogenic stresses. The small but frequent injuries to corals imposed by chronic fish predation are likely to result in a significant energetic drain on a coral colony's energy reserves and may even be the proximate cause of death for corals that are already stressed by the combination of direct anthropogenic disturbances and climate change (Cole et al. 2011).

Acknowledgements. This study was funded by the ARC CoE for Coral Reef Studies. We thank the staff at the Mahonia Na Dari Research and Conservation Centre for logistical support. This paper benefited from comments made by T. Petray, R. Lawton and 3 anonymous reviewers.

\section{LITERATURE CITED}

> Abramsky Z, Rosenzweig ML, Subach A (2002) The costs of apprehensive foraging. Ecology 83:1330-1340

Anderson TW (2001) Predator responses, prey refuges, and density-dependent mortality of a marine fish. Ecology 82:245-257

Anthony K, Hoogenboom MO, Maynard JA, Grottoli AG, Middlebrook R (2009) Energetics approach to predicting mortality risk from environmental stress: a case study of coral bleaching. Funct Ecol 23:539-550

> Bellwood DR, Hoey AS, Ackerman JL, Depczynski M (2006) Coral bleaching, reef fish community phase shifts and the resilience of coral reefs. Glob Change Biol 12:1587-1594

Bergman CM, Fryxell JM, Gates CC, Fortin D (2001) Ungulate foraging strategies: energy maximizing or time minimizing? J Anim Ecol 70:289-300

Berumen ML, Pratchett MS (2006) Recovery without resilience: persistent disturbance and long-term shifts in the structure of fish and coral communities at Tiahura reef, Moorea. Coral Reefs 25:647-653

Berumen ML, Rotjan RD (2010) New records of corallivory in the Red Sea. Coral Reefs 29(3):727

Berumen ML, Pratchett MS, McCormick MI (2005) Withinreef differences in diet and body condition of coral-feeding butterflyfishes (Chaetodontidae). Mar Ecol Prog Ser 287:217-227

Burdick D, Brown V, Asher J, Gawel M and others (2008) The state of the coral reef ecosystems of Guam. In: Waddell J (ed) The state of the coral reef ecosystems of the United States and Pacific Freely Associated States: 2008. NOAA Tech Memo. Center for Coastal Monitoring and Assessment Biogeography Team, Silver Spring, MD, p 465-510

Cole AJ, Pratchett MS, Jones GP (2008) Diversity and functional importance of coral-feeding fishes on tropical coral reefs. Fish Fish 9:286-307

Cole AJ, Pratchett MS, Jones GP (2009a) Coral-feeding wrasse scars massive Porites colonies. Coral Reefs 28:207

Cole AJ, Pratchett MS, Jones GP (2009b) Effects of coral bleaching on the feeding response of two species of coralfeeding fish. J Exp Mar Biol Ecol 373:11-15

Cole AJ, Pratchett MS, Jones GP (2010) Corallivory in tubelip wrasses: diet, feeding and trophic importance. J Fish Biol 76:818-835

Cole AJ, Lawton RJ, Pratchett MS Wilson Sk (2011) Chronic coral consumption by butterflyfishes. Coral Reefs (in press) doi:10.1007/s00338-010-0674-6

> Cox EF (1986) The effects of a selective corallivore on growthrates and competition for space between two species of Hawaiian corals. J Exp Mar Biol Ecol 101:161-174

> Done TJ, Dayton PK, Dayton AE, Steger R (1991) Regional and local variability in recovery of shallow coral communities: Moorea, French Polynesia and central Great Barrier Reef. Coral Reefs 9:183-192

Edmunds P, Lenihan H (2010) Effect of sub-lethal damage to juvenile colonies of massive Porites spp. Under contrasting regimes of temperature and water flow. Mar Biol 157: 887-897

> Fowler AJ (1990) Spatial and temporal patterns of distribution and abundances of chaetodontid fishes at One Tree Reef, southern GBR. Mar Ecol Prog Ser 64:39-53

Gochfeld DJ (2004) Predation-induced morphological and behavioral defenses in a hard coral: implications for foraging behavior of coral-feeding butterflyfishes. Mar Ecol Prog Ser 267:145-158

> Gochfeld DJ (2010) Territorial damselfishes facilitate survival of corals by providing an associational defense against predators. Mar Ecol Prog Ser 398:137-148

> Gregson MA, Pratchett MS, Berumen ML, Goodman BA (2008) Relationships between butterflyfish (Chaetodontidae) feeding rates and coral consumption on the Great Barrier Reef. Coral Reefs 27:583-591 
Grottoli AG, Rodrigues LJ, Palardy JE (2006) Heterotrophic plasticity and resilience in bleached corals. Nature 440: 1186-1189

Hall VR (2001) The response of Acropora hyacinthus and Montipora tuberculosa to three different types of colony damage: scraping injury, tissue mortality and breakage. J Exp Mar Biol Ecol 264:209-223

Hall VR, Hughes TP (1996) Reproductive strategies of modular organisms: comparative studies of reef-building corals. Ecology 77:950-963

Harmelin-Vivien M, Bouchon-Navaro Y (1981) Trophic relationships among chaetodontid fishes in the Gulf of Aquaba (Red Sea). Proc 4th Int Coral Reef Symp, Manila 2: $537-544$

Harmelin-Vivien ML, Bouchon-Navaro Y (1983) Feeding diets and significance of coral feeding among chaetodontid fishes in Moorea (French Polynesia). Coral Reefs 2: 119-127

Henry LA, Hart M (2005) Regeneration from injury and resource allocation in sponges and corals: a review. Int Rev Hydrobiol 90:125-158

Hixon MA (1997) Effects of reef fishes on corals and algae. In: Birkeland C (ed) Life and death of coral reefs. Chapman \& Hall, Melbourne, p 230-248

> Holmes TH, McCormick MI (2006) Location influences sizeselective predation on newly settled reef fish. Mar Ecol Prog Ser 317:203-209

Hourigan TF, Tricas TC, Reese ES (1988) Coral reef fishes as indicators of environmental stress in coral reefs. In: Soule DF, Kleppel GS (eds) Marine organisms as indicators. Springer-Verlag, New York, NY, p 107-135

Hughes RN (1980) Optimal foraging theory in the marine context. Oceanogr Mar Biol Annu Rev 18:423-481

Irlandi EA, Mehlich ME (1996) The effect of tissue cropping and disturbance by browsing fishes on growth of two species of suspension-feeding bivalves. J Exp Mar Biol Ecol 197:279-293

Jayewardene D (2010) Experimental determination of the cost of lesion healing on Porites compressa growth. Coral Reefs 29:131-135

> Jayewardene D, Donahue MJ, Birkeland C (2009) Effects of frequent fish predation on corals in Hawaii. Coral Reefs 28:499-506

> Langsrud $\varnothing$ (2003) ANOVA for unbalanced data: Use type II instead of type III sums of squares. Stat Comput 13: 163-167

Lehner NP (1996) Handbook of ecological methods, Vol 1. Cambridge University Press, Cambridge

Lenihan HS, Edmunds PJ (2010) Response of Pocillopora verrucosa to corallivory varies with environmental conditions. Mar Ecol Prog Ser 409:51-63

Lirman D (2000) Lesion regeneration in the branching coral Acropora palmata: effects of colonization, colony size, lesion size, and lesion shape. Mar Ecol Prog Ser 197: 209-215

Marshall PA, Baird AH (2000) Bleaching of corals on the Great Barrier Reef: differential susceptibilities among taxa. Coral Reefs 19:155-163

McClanahan TR, Baird AH, Marshall PA, Toscano MA (2004) Comparing bleaching and mortality responses of hard corals between southern Kenya and the Great Barrier Reef, Australia. Mar Pollut Bull 48:327-335

McIlwain JL, Jones GP (1997) Prey selection by an obligate coral-feeding wrasse and its response to small-scale disturbance. Mar Ecol Prog Ser 155:189-198

> Meesters EH, Pauchli W, Bak RPM (1997) Predicting regeneration of physical damage on a reef-building coral by regeneration capacity and lesion shape. Mar Ecol Prog Ser 146:91-99

Meesters EH, Hilterman M, Kardinaal E, Keetman M, de Vries M, Bak RPM (2001) Colony size-frequency distributions of scleractinian coral populations: spatial and interspecific variation. Mar Ecol Prog Ser 209:43-54

> Niedermüller SK, Schiemer LS, Herler J (2009) Food selection of a corallivorous butterflyfish Chaetodon austriacus in the Red Sea, with particular emphasis on size and fish symbionts of corals. J Fish Biol 75:1496-1504

Oren U, Benayahu Y, Loya Y (1997) Effect of lesion size and shape on regeneration of the Red Sea coral Favia favus. Mar Ecol Prog Ser 146:101-107

Oren U, Benayahu Y, Lubinevsky H, Loya Y (2001) Colony integration during regeneration in the stony coral Favia favus. Ecology 82:802-813

Peckarsky BL (1980) Predator-prey interactions between stoneflies and mayflies: behavioral observations. Ecology 61:932-943

Penin L, Michonneau F, Baird AH, Connolly SR, Pratchett MS, Kayal M, Adjeroud M (2010) Early post-settlement mortality and the structure of coral assemblages. Mar Ecol Prog Ser 408:55-64

Post DM, Palkovacs EP, Schielke EG, Dodson SI (2008) Intraspecific variation in a predator affects community structure and cascading trophic interactions. Ecology 89:2019-2032

Pratchett MS (2005) Dietary overlap among coral-feeding butterflyfishes (Chaetodontidae) at Lizard Island, northern Great Barrier Reef. Mar Biol 148:373-382

Pratchett MS (2007) Dietary selection by coral-feeding butterflyfishes (Chaetodontidae) on the Great Barrier Reef, Australia. Raffles Bull Zool S14:171-176

Pratchett MS, Trapon M, Berumen ML, Chong-Seng K (2011) Recent disturbances augment community shifts in coral assemblages in Moorea, French Polynesia. Coral Reefs (in press) doi:10.1007/s00338-010-0678-2

Pyke GH (1984) Optimal foraging theory: a critical review. Annu Rev Ecol Syst 15:523-575

Robertson R (1970) Review of the predators and parasites of stony corals, with special reference to symbiotic prosobranch gastropods. Pac Sci 24:43-54

Rodrigues LJ, Grottoli AG (2007) Energy reserves and metabolism as indicators of coral recovery from bleaching. Limnol Oceanogr 52:1874-1882

> Rotjan RD, Lewis SM (2008) Impact of coral predators on tropical reefs. Mar Ecol Prog Ser 367:73-91

> Rotjan RD, Dimond JL, Thornhill DJ, Leichter JJ, Helmuth B, Kemp DW, Lewis SM (2006) chronic parrotfish grazing impedes coral recovery after bleaching. Coral Reefs 25: 361-368

Samways MJ (2005) Breakdown of butterflyfish (Chaetodontidae) territories associated with the onset of a mass coral bleaching event. Aquat Conserv 15:S101-S107

> Schmitz OJ (2007) Predator diversity and trophic interactions. Ecology 88:2415-2426

> Sih A, Crowley P, McPeek M, Petranka J, Strohmeier K (1985) Predation, competition, and prey communities: a review of field experiments. Annu Rev Ecol Syst 16:269-311

Skilleter GA, Peterson CH (1994) Control of foraging behavior of individuals within an ecosystem context: the clam Macoma balthica and interactions between competition and siphon cropping. Oecologia 100: 268-278

Stephens DW, Krebs JR (1986) Foraging theory. Princeton University Press, Princeton, NJ

Taylor RJ 1984. Predation. Chapman \& Hall, London

Tricas TC (1989) Prey selection by coral-feeding butterfly- 
fishes: strategies to maximize profit. Environ Biol Fishes 25:171-185

Van Veghel MLJ, Bak RPM (1994) Reproductive characteristics of the polymorphic Caribbean reef building coral Montastrea annularis. III. Reproduction in damaged and regenerating colonies. Mar Ecol Prog Ser 109:229-233

Ward S (1995) The effect of damage on the growth, reproduction and storage of lipids in the scleractinian coral Pocillo-

Editorial responsibility: Tim McClanahan,

Mombasa, Kenya pora damicornis (L. linnaeus). J Exp Mar Biol Ecol 187: 193-206

Webster MS (2003) Temporal density dependence and population regulation in a marine fish. Ecology 84: 623-628

> Wellington GM (1982) Depth zonation of corals in the Gulf of Panama: control and facilitation by resident reef fishes. Ecol Monogr 52:223-241

Submitted: August 17, 2010; Accepted: November 2, 2010 Proofs received from author(s): January 14, 2011 